\title{
IAMJ
}

INTERNATIONAL AYURVEDIC MEDICAL JOURNAL

\section{AYURVEDA - A RAY OF HOPE IN VIRAL PANDEMIC OR COVID}

\section{Meenakshi Shukla ${ }^{1}$, Bipin Kumar Mishra ${ }^{2}$}

${ }^{1}$ Department of Samhita Siddhant, SKD Gov Ayurvedic College \& Hospital, Muzaffarnagar, Uttar Pradesh, India ${ }^{2}$ Departmen of Roga Nidaan, SKD Govt Ayurvedic College \& Hospital, Muzaffarnagar, Uttar Pradesh, India

\section{Corresponding Author: drmeenamd35@gmail.com}

https://doi.org/10.46607/iamj07p4062020

(Published online: September 2020)

Open Access

(C) International Ayurvedic Medical Journal, India 2020

Article Received: 07/09/2020 - Peer Reviewed: 26/09/2020 - Accepted for Publication: 26/09/2020

\section{Check for updates}

\section{ABSTRACT}

India is known for its traditional medicinal systems-Ayurveda, Siddha, and Unani. Medical systems are mentioned even in the ancient Vedas and other scriptures. The Ayurvedic concept appeared and developed between 2500 and $500 \mathrm{BC}$ in India. The literal meaning of Ayurveda is "science of life," because ancient Indian system of health care focused on views of man and his illness. It has been pointed out that the positive health means metabolically well-balanced human beings. Ayurveda is also called the "science of longevity" because it offers a holistic approach to live healthy and long life. It offers programs to rejuvenate the body through diet and nutrition. It offers treatment methods to cure many common diseases along with newer form of viral pandemics. Despite of worldwide efforts, trials of many drugs and in path of inventing vaccine. The COVID-19 requires an urgent harnessing of all knowledge/system of medicine which can bring proven prophylaxis \& therapeutic strategy. Ayurveda can serve the humanity, but it requires a pragmatic plan for intervention in this time of crisis along with immediate implementation. It is pertinent to reiterate that participation of Ayurveda in addressing COVID-19 challenge should be seen as extension of health care services and support to biomedical system.

Keywords: Ayurveda, Biomedical system, COVID-19

\section{INTRODUCTION}

We have witnessed one such unanticipated thing in pandemic in no time. Yes, its indeed COVID-19[1]. the beginning of 2020, which has turned out to be a This virus swiftly captured every notch and corner of 
the world with the invincible countries not being able to find the remedy of this. Many of developed and developing countries are finding it hard to deal with this "Rife". Government parsimony is being shattered, death tolls are rising in plenty, with the wax and wane happening around the world. Day to day new theories are coming forward with no exact intervention.

According to the WHO a pandemic involves the worldwide spread of new disease, while an epidemic remains limited to one city, region, or country. If an infection becomes widespread in several countries at the same time, it may turn into a pandemic. A new virus strain or subtype that easily transmits between humans can cause a pandemic, bacteria that becomes resistant to antibiotic treatment may also be behind the rapid spread ${ }^{[2]}$. In Ayurveda there is concept of epidemics under the term of Janapadodhwamsa where it is mentioned that due to either of deranged Vayu (air), Jala (water), Desha (habitat) and Kala (seasons),certain type of diseases arise from this which kill the mass of people ${ }^{[3]}$. Undoubtedly in the recent years, world is facing different type epidemic outbreak intermittently i.e. Ebola (2014), Zika (2015), MERS (2015), NIPAH (2001), SARS (2003) \& most recently Novel Coronavirus.(2019)

The current pandemic has had an unprecedented impact across the globe COVID-19. The disease with family Novel Corona virus which developed a disease known as Severe acute respiratory syndrome (SARS) which belongs to corona virus-2 family also called as SARS COV-2 or COVID-19 disease. Taking a look at its emergence which is from Hubei province of China in 2019 has become a pandemic in March 2020. Despite worldwide efforts to contain it, the pandemic is continuing to spread and requires a clinically proven prophylaxis and therapeutic strategy. The dimensions of pandemic require an urgent harnessing of all knowledge and various systems of medicine available globally ${ }^{[4]}$ Evidence of role played by Traditional Chinese Medicine cannot be overlooked as TCM was officially included in the guideline of diagnosis \& treatment of COVID-19. With a success of TCM managing a communicable pandemic. It is logical \& essential to explore how Ayurveda can help in addressing the COVID-19 challenge.

\section{Materials \& Method:}

An understanding of COVID-19 epidemiology \& pathogenesis as learned through Ayurveda. India, the country with long history \& continuous civilisation has its very own Science of life Ayurveda It is a highly contagious viral infection caused by Novel Coronavirus. Transmission of this virus has been ruled out by direct contact and droplet aerosol infection. The symptoms are fever, dry cough, sore throat, tiredness, chest pain, difficulty in breathing etc. ${ }^{[5]}$ This new disease has neither established treatment nor any vaccination. Modern medical scientists are doing their best to get rid of this pandemic. Prevalent antiviral medicines have been tried on patients, but no satisfactory results are found yet. This is the major concern of the medical scientists. This review Article is an attempt according to Ayurvedic classics towards prevention of infectious diseases such as COVID-19, $\mathrm{H}_{1} \mathrm{~N}_{1}$, SARS, MERS etc. Ayurveda has clearly narrated pandemic diseases under the heading of Janpadodhwansa. The cause varies but the medium through which such pandemics spread are same which humanity has faced in the history of pandemic. The Ayurveda suggests Deranged Vayu, Jala, Desh, Kala. According to Sushrut Samhita in Sansargaja Upsargaja or Aupsargik Roga ${ }^{[6]}$ All falls in this category one more theory of Aaguntuja Vikara /Krimij Roga/Bhuta Vikara can be incorporated in this. As per Acharayas many diseases which are not mention by name classics can be treated according to Dosha-Dushya\& SamuthanVishesh. ${ }^{[7]}$ As per the verse-

"Vikaranaamakushlona Jvihat Kadachanah, NahiSarvavikaranaam Namtosti DhruvaSthitha.||"

In COVID -19, if we analyse the sign and symptoms according to Ayurvedic classics which contemplate that Aagantuj Vikaras can be transformed into $\mathrm{Ni}$ jaVikaras. Kaphavota Sansargaja Jwara in the beginning acquires status of full Sanhipatajjwara. Undergoing to sign \& symptoms of this disease the pathophysiology Samprapti can be explained as if Jwara of Pitta having Ushna, Sneha \& dravaguna have a pathological effect on Kapha \& then this unstable Kapha \& 
Pitta causes Syandam \&Shoshan. If dosha-dushya continues to dwell, dhatupaka happens which bring Shawsa as Upadrava. Later these stages if continues can bring Ojonasha (state of shock which can lead to mechanical support or Atyayik Chiktsa. In this disease the RogaMarga is Abhyantaraas Jwara, Swasa, and Kasa, 3 major symptoms belong to this Marg (pathways of disease). There is PranvahSrotodushti as there is severe respiratory distress, frequent breathlessness, wheezing sound, obstruction in alveoli along with other symptoms, sometimes leading to death. The seat of affliction of this disease is primarily Uras (Chest region). In Nutshell COVID-19 can be corelated as Aagantuj Sannipataja Jwara, which is of VataKapha predominance ${ }^{[8]}$.

This Jwara can be classified as being Agantuj (external) caused by Bhoot Abhisanga ${ }^{[9]}$ which aggravates all the three Doshas. Hence nomenclature as Sannipata. The spread and affliction caused by the virus can be understood in Ayurved. According to Ayurveda, Agantujwara is to be treated as a NijaJwa$r a$ caused by imbalance of doshas.

\section{DISCUSSION}

The etiology of this illness is contributed Vata-Kapha predominant fever with all the characteristics of Janpadodhwansavikara. It is highly contagious disease. The methods by which contagion spread is described in Sushurta Samhita under the chapter pfKusthaNidaanChapter-5. ${ }^{[10]}$

Skin diseases fever, consumption, conjunctivitis and all contagious diseases spread from person to person by indulgence in bodily contact, by coming in contact with another's breath, eating with others in same plate, sharing of bed and seat, through contact with clothes, ornaments and cosmetics.

Interventions: Before starting the intervention, it is very necessary to assess prognosis and advice timely referrals to secondary or tertiary care facilities as per the need of patient. An extra \& utmost care should be taken while treating COVID-19 patients suspected to have contracted infection of SARS COV-2. In contrary Ayurveda has enormous potentials to provide/easing\& innovative insights.
Preventive Measures: Initially follow hand and respiratory hygiene, with avoidance of touching eyes, nose, face etc. along with social distancing which can be incorporated under Nidaanparivarjan.

The second approach is the vastness of Dincahrya, Ritucharya, indulgence in Swasthvritta, Sadavritta ${ }^{[11]}$ which include personal, social etiquettes and Achara Rasayanas. Utmost care of both types of urges, suppressible \& non suppressible. As the cause of epidemic is considered as adharma which results in Pragyapradh which leads to Janpadodhwans. Have a look at AYUSH Ministry protocol. Immunity boosting measures, such as intake of warm water which act as a doshapachan, practice of various types of Yogasana, Pranayam, Kadha, Turmericmilk, Nasya, Gandush, Rasayana drugs which are proposed in Janpadodhwansadhiyayae. Grasayanadravyas i.e. Chywanprash, Agastyaharitika, Amritbhallataka, Brahmrasayana.

Curative Measures: Going through various literatures \& studies done, According to Roga. Rogibala, exposed asymptomatic patients should be intervene with Sanjeevanivati, Sitopaladi, TalishadiChurna, Yashtimadhu, Chitrkadivati along with Brahmrasayana, Chywanprash and preventive measures.

With moderate to severe COVID-19 symptoms use of Pippalirasayana, Laghu-Vasantmalati, Sanjeevanivati, TribhuvanKriti rasa, BhritVata Chintamani rasa, Mrityunjaya rasa, Siddha Makardhwaj etc. Use Ushnodak as Anupana in all cases of COVID.

Drug processing Anti-inflammatory, Antiviral properties specially Tikta Rasa Dravyas and immunomodulators such as Guduchi, Kaalmegha, Yashtimadhu, Ashwagandha, Tulsi etc. should be used. Nasal drops of Anu-Tail \& use of various spices should be incorporated in diet.

\section{CONCLUSION}

Ayurveda has enough potential \& possibilities to be employed both for prevention \& treatment of COVID19. Thus, will provide am important opportunity for learning \& generating credible evidences. With this age-old system of medicine, we are able to create sci- 
entific evidence $\&$ to present the world community a plan of intervention in time of global crisis.

Treatment protocol must indulge the prakriti, Adhishthan \& Samuthan. The virulence of any type of viral pandemic has been always inversely proportional to the immunity. Immunity which can be compared as Bala in Ayurveda as Sahaj, Kalaj \& Yuktikrut. The measures which surely increase Shareerik Bala \& Mansik Balas are immunomodulators. Increase mental health by yoga, meditation and lung capacity by Pranayam. Never violate the harmony with the environment and keep doing prayers and Daivavyapashrayachikitsa.

\section{REFERENCES}

1. Zhou P, Yang XL, Wang XG, HUB Zhang I, Zhang I, Zhang W, el al. A pneumonia outbreak associated with a new corona virus of probable bat origin. Nature 2020; 579:270-3, https://doi.org/10.1038/S41586-020-2012-7

2. Rastogi $\mathrm{S}$, viral epidemics and traditional health care systems: It's time to act honestly, proactively and collectively. Annal Ayurvedic Med 2020;9:9-11

3. Agnivesha: Charka Samhita, Ayurveda Deepika, commentary by Chakrapanidutta; Ed. Pt. Y T Acharya; Chaukhamba Surbharati Prakasham Varanasi, 2016; Viman Sthan Chapter no.3verse no.6 Page no.241

4. Dong E, Du H, Gardner L. An interactive web-based dashboard to track COVID-19 in real time. Lancet Infect Dis 2020.https://doi.org/10.1016/514733099(1020)30120-30121

5. Wang Chen, Horby Peter W, Hayden Frederick G, Gao George F. A novel coronavirus outbreak of global health concern. The Lancet. 2020;395(10223):470 473. doi: 10.1016/S0140-6736(20)30185-9. [PMC free article] [PubMed] [CrossRef] [Google Scholar]

6. Sushuruta, Sushurut Samhita, Nibandhasangraha commentary by Sri Dalhanacharya; Ed. Pt. Y T Acharya; Chaukhamba Surbharati Prakasham Varanasi, 2018; Nidaansthahan Chapter no. 5 Verse no.32-33-page no. 251.

7. Agnivesha: Charka Samhita, Ayurveda Deepika, commentary by Chakrapanidutta; Ed. Pt.Y T Acharya; Chaukhamba Surbharati Prakasham Varanasi, 2016; Sutra Sthan Chapter no.18 verse no.44 Page no.109

8. Agnivesha: Charka Samhita, Ayurveda Deepika, commentary by Chakrapanidutta; Ed. Pt. Y T Acharya;
Chaukhamba Surbharati Prakasham Varanasi, 2016; ChiktsaSthan Chapter no. 3 verse no.92 Page no.406

9. Agnivesha: Charka Samhita, Ayurveda Deepika, commentary by Chakrapanidutta; Ed. Pt. Y T Acharya; Chaukhamba Surbharati Prakasham Varanasi, 2016; ChiktsaSthan Chapter no.3 verse no.111-114 Page no. 406

10. Agnivesha: Charka Samhita, Ayurveda Deepika, commentary by Chakrapanidutta; Ed. Pt. Y T Acharya; Chaukhamba Surbharati Prakasham Varanasi, 2016; Sutra Sthan Chapter no.19 verse no.7 Page no.106

11. Agnivesha: Charka Samhita, Ayurveda Deepika, commentary by Chakrapanidutta; Ed. Pt. Y T Acharya; Chaukhamba Surbharati Prakasham Varanasi, 2016; Sutra Sthan Chapter no.8 verse no.17-29 Page no.59

\section{Source of Support: Nil \\ Conflict of Interest: None Declared}

How to cite this URL: Meenakshi Shukla \& Bipin Kumar Mishra: Ayurveda - A Ray of Hope in Viral Pandemic or Covid. International Ayurvedic Medical Journal \{online\} 2020 \{cited September, 2020\} Available from: http://www.iamj.in/posts/images/upload/2494_2497.pdf 